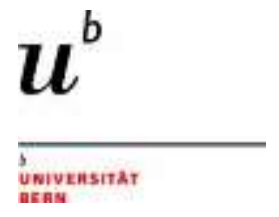

\title{
Using Firm-Level Case Studies to Address Trade Facilitation Challenges in Southern Africa
}

\author{
Clarence Siziba \\ University of Bern, World Trade Institute \\ clarence.siziba@wti.org
}

\section{Abstract}

This paper will analyse a survey on a range of firm-level case studies detailing the main de jure and de facto trade barriers that companies face in doing business in Southern Africa. Reference is made to previous studies on trade barriers within the region. The relevance of the Trade Facilitation Agreement to SADC going forward will also be assessed, following which recommendations will be made regarding the policy implications for SADC's trade agenda as well as the development impact of measures to eliminate non-tariff barriers for SADC citizens.

Research for this paper was funded by the Swiss State Secretariat for Economic Affairs under the SECO / WTI Academic Cooperation Project, based at the World Trade Institute of the University of Bern, Switzerland.

SECO working papers are preliminary documents posted on the WTI website (www.wti.org) and widely circulated to stimulate discussion and critical comment. These papers have not been formally edited. Citations should refer to a "SECO / WTI Academic Cooperation Project" paper with appropriate reference made to the author(s). 


\title{
Introduction
}

\begin{abstract}
"A broad definition of trade facilitation encompasses policies to reduce trade transaction costs, including "behind-the-border" policy reforms and the reduction of transaction costs resulting from cumbersome administrative customs, documentary requirements and border procedures that affect cross-border movement of goods and services. The term also covers simplification of the logistics, documentation and customs procedures involved in transiting goods through ports and land borders. It refers, too, to "domestic" policies and institutional structures that create an enabling environment for trade. Finally, it can take in harmonization of national and regional standards with international standards."1
\end{abstract}

Surveys are normally used where individual responses are required - in the present instance, different companies. 'Surveys include the use of a questionnaire - an instrument specifically designed to elicit information that will be useful for analysis.' ${ }^{2}$ The design of a survey should respond to both the research question and the aims of the study. The aim of the the South African Institute of International Affairs (SAIIA) and the Gesellschaft für Internationale Zusammenarbeit (GIZ) in conducting this survey was to identify key business constraints for firms operating in the Southern African Development Community $(\mathrm{SADC}) .{ }^{3} \mathrm{~A}$ secondary aim was to use the firm level data to open dialogue on policy choices to address the concerns of business

\footnotetext{
${ }^{1}$ UNECA 'Assessing Regional Integration in Africa VI: Harmonizing Policies to Transform the Trading Environment' 23.

${ }^{2}$ Earl Babbie, The Practice of Social Research (Wadsworth 2010) 255.

${ }^{3}$ The Southern African Development Community (SADC) was established in 1992 and is made up of 15 Members. The SADC Protocol on Trade (1996) governs trade cooperation issues; Annex II of the Protocol deals specifically with trade facilitation.
} 
people in SADC. Overall, the barriers identified are instrumental in informing policymakers about trade facilitation matters such that strategies can be devised to address them.

This is not the first survey of its kind; various other surveys have been conducted with a view to assessing the ease of doing business in Southern Africa as well as identifying barriers to trade within the region. ${ }^{4} \mathrm{~A}$ common outcome of these surveys is that while policy recommendations were made following the analysis, these were not actioned; if so, this was left to the bare minimum. Indeed, some companies involved in the current survey expressed their misgivings about possible outcomes of the exercise, given the fact that they had already participated in more or less similar studies before, with little results. ${ }^{5}$ At this juncture, it will suffice to mention this point, as it will be expanded upon below.

Nevertheless, what makes the present survey different from the rest is that it not only had the backing of SADC from the initial stage, but also because the SADC Secretariat was instrumental in helping to conduct the exercise. Appeal to SADC was made in writing up the results of the interviews that the researchers conducted. This was done particularly for clarification or edification; for instance, on Regional Transit Bonds. Not much has been written about them, but they could provide a remarkable example of how to use regional initiatives for the benefit of the private

\footnotetext{
${ }^{4}$ Some of these surveys include the following: World Bank Regional Investment Climate Assessment for SADC; World Economic Forum Global Competitiveness Index; World Bank Ease of Doing Business Survey; Ernst \& Young Africa Attractiveness Survey; World Bank Enterprise Surveys; Business Climate Assessments by the Southern African Regional Poverty Network (SARPN), Association of SADC Chambers of Commerce and Industry (ASCCI) and Afrika-Verein. Some of these will be discussed below.

${ }^{5}$ For example, Lobatse Clay Works indicated that they had participated in similar surveys before, but since nothing had come of it, they did not feel that another survey would add any value. The case study is available at: SAIIA, GIZ 'Lobatse Clay Works' http://www.thetradebeat.com/sadc-businesscase-studies/lobatse-clay-works.
} 
sector. ${ }^{6}$ Whether or not this will translate into tangible policy results within the short to medium term is yet to be seen.

The present author dealt with the materials generated by various researchers across the spectrum of survey companies in 2012 and since then watched the development of the case studies over the years. Consultations were held with some of the researchers as well as survey coordinators in order to arrive at conclusions that hinge on the primary data, specifically with respect to the more nuanced aspects. There is a lot that can still be deciphered from the study output to form generalisations and paint a picture within which to analyse trade facilitation issues within SADC.

\section{Survey Description}

\section{Sampling}

Data collection is necessary to test a hypothesis. Hence, the manner in which research subjects are selected is very important as it influences the quality of the research produced. ${ }^{7}$ 'The purposive sampling technique, also called judgment sampling, is the deliberate choice of an informant due to the qualities the informant possesses. $^{8}$ In this type of sampling, the researcher makes a deliberate choice regarding who to speak to in order to collect information to answer their research question. Purposive sampling can either be selective or theoretical. Selective

\footnotetext{
${ }^{6}$ See Case Study 6: Regional Transit Bonds in Lesley Wentworth "Regional Business Barriers: Unlocking Economic Potential in Southern Africa" available at http://www.saiia.org.za/news/regionalbusiness-barriers-unlocking-economic-potential-in-southern-africa. ${ }^{7}$ Imelda T. Coyne, 'Sampling in qualitative research. Purposeful and theoretical sampling; merging or clear boundaries?' (1997) 26 Journal of Advanced Nursing 623, 623.

${ }^{8}$ Maria Dolores C. Tongco, 'Purposive Sampling as a Tool for Informant Selection' [2007] , 147.
} 
sampling is a deliberate choice of subjects based on preconceived ideas, while theoretical sampling refers to the choice of subjects based on a developing sample. ${ }^{9}$

During an interview, one of the lead researchers on the project, Ms Lesley Wentworth, revealed that the entire interview process was not conducted using a cookie cutter approach. ${ }^{10}$ General guidelines and a simple questionnaire were produced to allow for uniform responses to be collected. This form was sent out to various companies within the SADC region with a number of consultants contracted to SAllA. The companies were chosen in concert with the regional business organisations that SAIIA and GIZ worked with on this project. ${ }^{11}$ It lends credit to the researchers that they eventually found a way to synergise and present the data they collected in a uniform format.

In a purposive sample, respondents to the survey must be competent to answer questions. $^{12}$ The present study used responses from relevant senior employees and/or proprietors at the firms under surveillance. At face value, they are all competent to answer questions. This helps in the external validation of the accuracy and relevancy of responses to the research question. The choice of survey respondents who have recent experience is important for two reasons. ${ }^{13}$ Firstly, their answers, being based on recent experience, will be more accurate. Secondly, people with recent experience may be more willing to talk about it.

\footnotetext{
${ }^{9}$ Coyne, 'Sampling in qualitative research. Purposeful and theoretical sampling; merging or clear boundaries?' 628.

${ }_{10}$ Lesley Wentworth is the Programme Manager for the Economic Diplomacy Programme at the South African Institute of International Affairs. She can be reached at lesley.wentworth @saiia.org.za.

${ }^{11}$ These include the Association of SADC Chambers of Commerce and Industry (ASCCI); the South African Chamber of Mines; The SADC Truckers Association and the Southern African Generic Medicines Association (SAGMA) among others.

${ }^{12}$ Babbie, The Practice of Social Research 258.

${ }^{13}$ C. Sibona and S. Walczak, 'Purposive Sampling on Twitter: A Case Study', January 20123514.
} 
Nevertheless, purposive sampling is replete with bias. This is because the researcher chooses specific people to answer a specific set of questions. The bias is further amplified by the researcher's 'assumption' regarding the validity and reliability of responses prior to receiving results of the survey given the position of each of the respondents. Conversely, a random sample tends to 'externally validate the data collected' since the sample is considered less-biased than that in purposive samples. ${ }^{14}$ All the same, it can also be argued that the strength of the purposive sampling method lies in its internal bias. Prior knowledge of one's sources, area of study and audience are essential in facilitating the greatest reliability. ${ }^{15}$ This also goes on to inform one's choice of research subjects. It follows, therefore, that one should pay attention to research design in order to reduce bias in results. ${ }^{16}$

Babbie suggests various strategies in which survey questions can be framed in order to ensure accuracy and reliability of data collected during the research project. ${ }^{17}$ Questions should be framed clearly. ${ }^{18}$ This means that, where possible, relevant terms should be explained. Furthermore, the simplest configuration should be used since the conception of something from one place to another can be different. This is especially important given the fact that various languages are used in business across Southern Africa, including the use of English, Portuguese and French. Respondents must also be willing to answer questions. ${ }^{19}$ It can be assumed that the respondents to the survey were willing to answer questions since they are referred to by name in the text. Additionally, the naming of the companies is essential because

\footnotetext{
${ }^{14}$ Tongco, 'Purposive Sampling as a Tool for Informant Selection' 154.

15 Barbara A. Kitchenham and Shari Lawrence Pfleeger, 'Principles of Survey Research Part 2: Designing a Survey' (2002) 27 SIGSOFT Softw. Eng. Notes 18, 19.

${ }^{16}$ Kate Kelley, Belinda Clark, Vivienne Brown, and John Sitzia, 'Good practice in the conduct and reporting of survey research' (2003) 15 International Journal for Quality in Health Care 261, 263.

17 See generally Babbie, The Practice of Social Research 256-266.

${ }^{18}$ Babbie, The Practice of Social Research 257.

${ }^{19}$ Babbie, The Practice of Social Research 259.
} 
the results can be attributed directly to certain participants, operating within a particular geographical area and facing a specific set of constraints. It is envisaged that in deciding on new policies, SADC would then be better able to respond to the specific requirements of each sector.

\section{Ethics}

The term ethics refers to the philosophy of what is right and wrong. ${ }^{20}$ Research centres on the production and testing of new knowledge. As such, it is important that the research findings be true as well as reliable. Validity of research data measures the accuracy of the data collected; reliability measures the extent to which the same research project can be replicated elsewhere. ${ }^{21}$ Essentially, both concepts imply the need for the application of a rigorous approach to the research process in order to generate composite empirical research output. Other researchers prefer to use the terms dependability and integrity as they deem them to be a more accurate reflection of the measurement of the overall research design and process. ${ }^{22}$ It is important to note, however, that what is deemed morally upright or ethical will vary both from one group and from one situation to another.

In order to protect the identity of the survey participants, care must be taken to ensure confidentiality of results. ${ }^{23}$ This does not necessarily apply in the present case where the research essentially hinges on accurate reporting by the target

\footnotetext{
${ }^{20}$ Adil E. Shamoo and Cheryl D. Dunigan, 'Ethics in Research' (2000) 224 Experimental Biology and Medicine 205, 205.

${ }^{21}$ T. Long and M. Johnson, 'Rigour, reliability and validity in qualitative research' (2000) 4 Clinical Effectiveness in Nursing 30, 30-31.

${ }^{22}$ Long and Johnson, 'Rigour, reliability and validity in qualitative research' 31-32. See further on Page 33-34 for other alternative terms as well as strategies to facilitate rigour in research.

${ }^{23}$ Babbie, The Practice of Social Research 67. For a brief discussion on the ethical dimensions of research, particularly in relation to protecting research subjects, see Denis Walsh and Soo Downe, 'Appraising the quality of qualitative research' (2006) 22 Midwifery 108-119.
} 
companies. Being a purposive sample that was carefully selected from a small pool also necessitates the need to disclose the identity of the survey participants and and/or respondents.

The survey under examination was conducted with full disclosure to survey participants with respect to the nature of the information required as well as the manner in which said information would be utilised and disseminated. ${ }^{24}$ It follows from this that the researcher tried to protect the integrity of survey participants. Even in detailing the responses given by each of the survey participants, the author presents the information in a matter-of-fact way with no obvious evidence of exaggeration or embellishment. The names of companies which responded have also been recorded, allowing anyone who seeks to clarify certain points to be able to contact the relevant firm and ask for further details.

\section{Results of Previous Studies}

As alluded to above, some studies on key constraints to doing business in SADC have been conducted by other actors. This paper will not attempt to discuss all other similar studies, but will focus on a few of the most relevant in this context.

\section{World Bank Regional Investment Climate Assessment of SADC ${ }^{25}$}

This research was designed to assess the level of integration in SADC as well as trade flows within the region. The study found that in 2011, although SADC's share

\footnotetext{
${ }^{24}$ The results of the survey have been published at: http://www.thetradebeat.com/sadc-businesscase-studies.

${ }^{25}$ Alberto Behar and Lawrence Edward, 'How Integrated Is SADC? Trends in Intra-Regional and Extra-Regional Trade Flows and Policy' (The World Bank 2011).
} 
of world trade had fallen, overall trade within the region had increased, dispelling fears that the region is not well-integrated. ${ }^{26}$ With respect to non-tariff barriers to trade, it was found that, based on the level of development in the region, although "obstacles to trade are high, ... the overall trading environment and market access and border administration in particular (but not transport and communications infrastructure) are on average better in the SADC region than the rest of the world." ${ }^{27}$ An important point raised in this study is that the landlocked countries in SADC will need to go a lot further in addressing these non-tariff barriers because they stand to lose out on a lot more trade without such reforms. ${ }^{28}$ This particular observation is interesting because it highlights how peculiar local conditions should influence the manner in which both business people and policymakers consider how they assess the trading environment. Benchmarking SADC against regions with similar levels of development reveals a larger spectrum of constraints than would be assessed in a single region. The concerns raised with transport and communications infrastructure have also come up within the SAllA studies, and these will be discussed below.

\section{Afrika-Verein SADC Business Climate 2010/11 Outlook 2012 29}

Afrika-Verein conducts business climate surveys to assess the performance and business constraints of German firms operating in SADC - this was Afrika-Verein's sixth such study. It is interesting that for the first time, the focus of the Afrika-Verein study was on was not only on German business, but also on business from the BRICS countries. This is an important digression from practice because it allows for

\footnotetext{
26 Ibid at 4.

27 Ibid at 19.

28 lbid.

${ }^{29}$ Rand Merchant Bank and Afrika-Verein 'SADC Business Climate 2010/1:1 Outlook 2012' (2011).
} 
a different kind of comparative analysis to be followed. The main challenges to conducting business in the region were the following: skills shortages, crime and corruption, as well as an uncertain regulatory environment. ${ }^{30} 55,4 \%$ percent of the survey respondents were satisfied with the business environment in SADC. The fact that less than $7 \%$ considered the business environment to be unconducive is testimony to improvements in the business climate. ${ }^{31}$ Nevertheless, the challenges they raised need to be addressed in order for there to be greater satisfaction amongst firms conducting business in the region.

\section{Private Sector Involvement in African Regional Economic Integration (2011)}

This research was an assessment of private sector participation in economic policy design at the regional level within the EAC, ECOWAS and SADC. Private sector involvement is essential in assisting policymakers to design policies responsive to the needs of business people within the region. This is one of the fundamental points raised by the SADC Business Case Studies. Any policy deliberations that do not take into account the concerns of the private sector, to which much of the outcomes will apply, falls short of its mark. The study noted that while it was found desirable by both the private sector and government to engage at this level, the problem is that none of the regional bodies "has a defined policy for what decision at what stage of the process which kind of private sector organisation has to be involved and has a

\footnotetext{
${ }^{30} \mathrm{Ibid}$ at 10.

${ }^{31} \mathrm{lbid}$ at 8.

32 GIZ, 'Private Sector Involvement in African Regional Economic Integration' (2011)http://www2.gtz.de/wbf/4tDx9kw63gma/GIZ NEDA PS Involvement in REI final.pdf.
} 
voice in the decision making process. ${ }^{33}$ Such a situation lends itself to inefficient and unresponsive decision-making at the regional policy level.

Article 23 of the SADC Treaty provides that the non-governmental organisations and associations shall be involved in integration processes. ${ }^{34}$ This was further amplified in the Regional Indicative Strategic Development Plan (RISDP), which is the blueprint for SADC's integration and development agenda. ${ }^{35}$ This means that the private sector's involvement in decision making was envisaged from the establishment of SADC and should inform its processes.

\section{Ernst and Young (EY) Attractiveness Survey 2014}

EY Attractiveness Surveys are designed to assess the investment climate of a region with a view to assisting investors to make viable business decisions, while at the same time ensuring that governments respond to various barriers faced by investors locally. The current survey is the fourth such instalment by Ernst and Young. Unlike the other studies which are pitched at analysing firm-level responses, the EY Survey compiles the views of a cross section of local and international opinion leaders. This is a strength in that it allows the flourishing of independent opinions; however, there is a danger that some of the views may be removed from the reality on the ground.

The EY Survey noted that while significant progress has been made in addressing the concerns of investors in Africa, "perceptions about the continent often remain

${ }^{33}$ The benefits of public-sector participation in policymaking are described on pages 3-10 of the Report. These include greater legitimacy for decisions made, an easier climate for implementation and influencing regionl processes and policies amongst others.

${ }_{34}^{34}$ Art. 23 Treaty of the Southern African Development Community

35 SADC Regional Indicative Strategic Development Plan

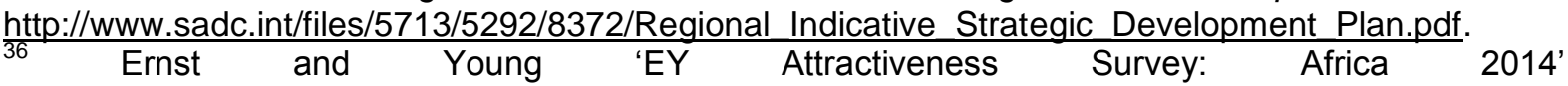
http://www.ey.com/Publication/vwLUAssets/EY-attractiveness-africa-2014/\$FILE/EY-attractivenessafrica-2014.pdf. 
stuck in the past." 37 It is this perception gap which needs to be addressed before significant progress can be made in other spheres. The view of Africa as a Dark Continent which needs to be saved has been held for a long time. The emergence of the narrative of Africa as the last economic frontier is a direct contrast to this. Relative to other destinations, Africa is now seen as a prime investment destination. ${ }^{38}$ Nevertheless, while African FDI in-flows have increased in the last decade, they still form less than $5 \%$ of global flows. ${ }^{39}$

\section{Phase I}

During Phase I of the survey, the questionnaire was sent to 90 companies based on recommendations from various business associations that the researchers approached prior to conducting the survey. Following the survey, 45 of the case studies were then published online after rigorous verification. ${ }^{40}$

\footnotetext{
${ }^{37}$ This is also evident in the manner in which some companies in the Business Case Studies dismiss certain incidents as being part of the fabric of African business practice.

${ }^{38}$ EY Attractiveness Survey 'EY Attractiveness Survey' Africa ranked $2^{\text {nd }}$ overall in the current survey. 39 Ibid 5.

40 These can be accessed here: SAllA "Business Case Studies" http://www.thetradebeat.com/sadcbusiness-case-studies.
} 


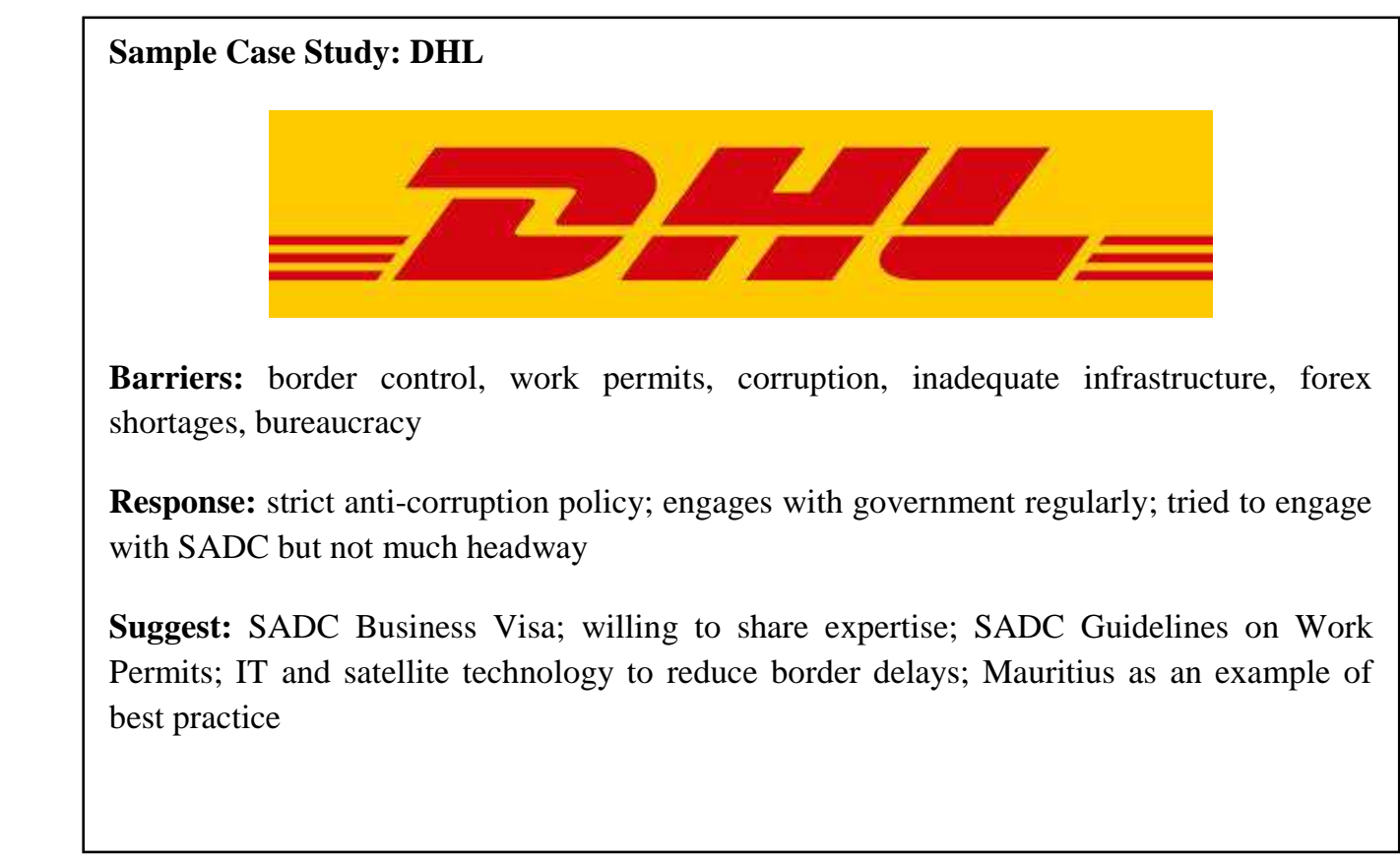

Source: http://www.thetradebeat.com/sadc-business-case-studies/dhl (Author's formatting)

While the survey was being carried out, a list of then top ten barriers to doing business in SADC was computed using national and regional case studies that had been conducted by other entities prior to the present study. From this analysis, the top ten business barriers that were identified were:

1. Access to and cost of finance.

2. Tax rates and/or administration (including direct and indirect taxes, double taxation policies and harmonisation).

3. Access to skilled labour (including issues related to the free movement of people in the region).

4. Economic and regulatory policy uncertainty. 
5. Fluctuations of the exchange rate/foreign currency regulations, including with respect to remittances.

6. Customs regulations, procedures and bureaucracy.

7. Supply of reliable and efficient infrastructure, including transport, telecommunications, IT and energy.

8. Corruption.

9. Inefficient bureaucracy, including transparency of rules and regulations, business licensing and investment permits.

10. Non-tariff and other trade barriers, including TBT, SPS and SQAM issues. ${ }^{41}$

Once the information from the case studies was distilled and cross-referenced with the previous desk analysis results, it emerged that the top barriers mentioned by each of the respondents were: customs regulations; infrastructure; access to skilled labour; inefficient bureaucracy; corruption; and access to finance. ${ }^{42}$

\footnotetext{
${ }^{41}$ For a more detailed analysis, see Catherine Grant-Makokera, Geoffrey Chapman, Lesley Wentworth "Top 10 Business Constraints in SADC: An Analysis of Business and Investment Climate Surveys" http://www.thetradebeat.com/sadc-articles/top-10-business-constraints-identified-in-thesadc-region.

42 Talitha Bertelsmann-Scott; Catherine Grant-Makokera; David Graf "Making Key Business Constraints in SADC Tangible: Experiences of the Private Sector" 4 http://www.thetradebeat.com/doc download/5-making-business-constraints-tangible.
} 


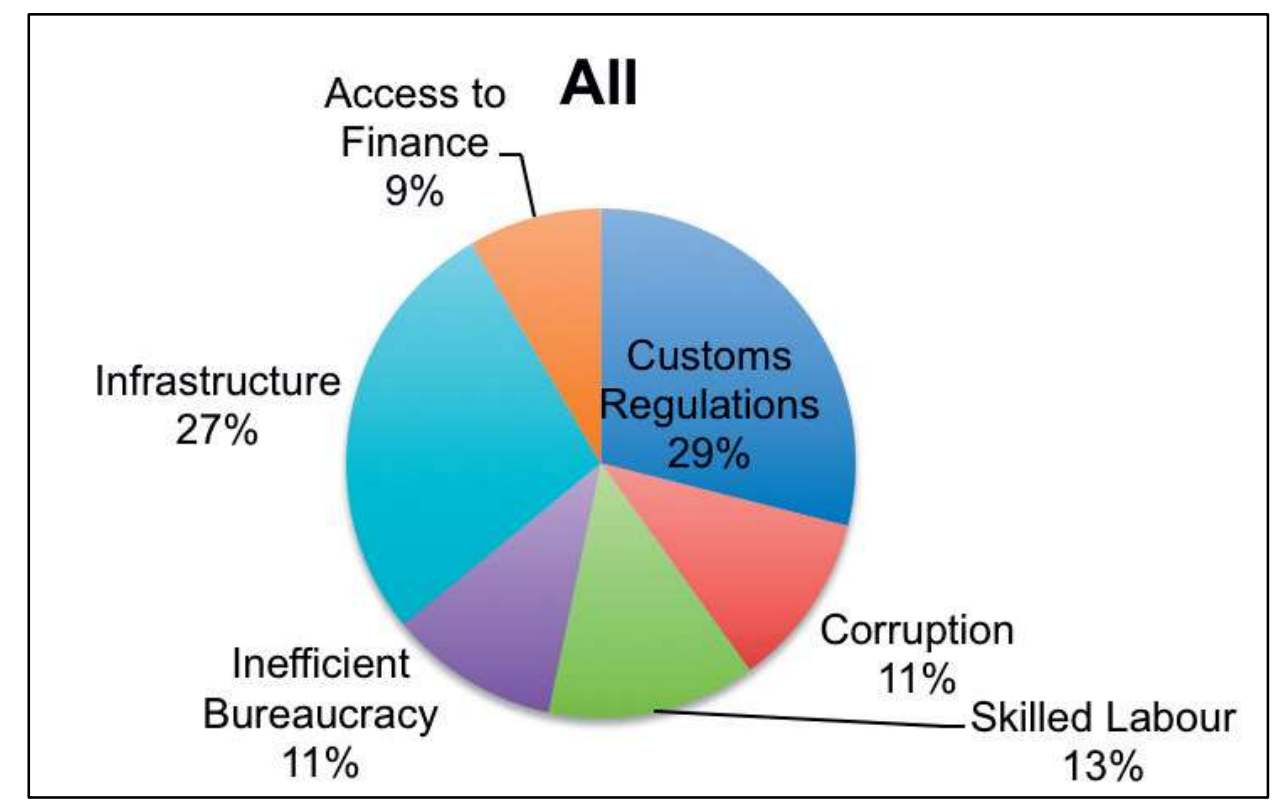

Source: Talitha Bertelsmann-Scott; Catherine Grant-Makokera; David Graf "Making

Key Business Constraints in SADC Tangible: Experiences of the Private Sector"

It is interesting that corruption came up so strongly in the survey. In fact, two contrasting perspectives emerge in the manner in which certain firms deal with corruption; for example, DB Schenker, a German logistics concern and Vodacom, a South African telecommunications company. According to DB Schenker, customs regulations and procedures are viewed as being "of no concern because these are basic directives which they have to adhere to as any other law-abiding citizens". ${ }^{43}$ However, in the same breath, "corruption was described as an African habitual practice which does exist and will always be there. ${ }^{44}$ It is rather peculiar that a company professing to uphold the law would be so flippant about corruption. One would not be remiss in arguing that such utterances could be the result of having engaged in one form of corruption or another. Vodacom on the other hand "employs a strict anti-corruption policy in the hope that this will eventually send significant signals to the region that corruption is not in anyone's interest and that business in

\footnotetext{
${ }^{43}$ SAIIA, GIZ "DB Schenker" http://www.thetradebeat.com/sadc-business-case-studies/db-schenker. ${ }^{44}$ Ibid.
} 
Africa can be done without bribery." ${ }^{45}$ It is hoped that more businesses will engage in this philosophy while doing business in Southern Africa as this would ultimately reduce the barriers they face and encourage more investment in the region.

The SADC Protocol Against Corruption was signed in 2001 to assist in the detection, prevention and combatting of corruption regionally. Corruption hampers development, particularly in developing countries. "It exacerbates all the other problems that beset the region. It frustrates and impedes all efforts to solve those problems." This means that legitimate policy goals will be derailed where corruption is rife. Efforts to redress corrupt practices will also fail since corruption will form part of the fabric of the operating environment. Therefore it is not enough to merely have anti-corruption laws and policies in place. Rather, care must be taken to ensure that policing mechanisms are utilised effectively to combat the scourge. The SADC Lawyers Association has commissioned a study on the implementation of the AntiCorruption Protocol. It will be interesting to see what the outcome of this study will be, particularly with respect to the effects that corruption has on trade within the region.

\section{SADC Regional Indicative Strategic Development Plan (RISDP)}

The SADC Regional Indicative Strategic Development Plan (RISDP) was adopted by the SADC Summit in 2003 as a blueprint for the regional integration agenda of SADC from 2005-2020. ${ }^{46}$ "The ultimate objective of the plan is to deepen integration in the region with a view to accelerate poverty eradication and the attainment of

\footnotetext{
45 SAIIA, GIZ "Vodacom (South Africa)" http://www.thetradebeat.com/sadc-business-casestudies/vodacom-south-africa.

${ }^{46}$ SADC Regional Indicative Strategic Development Plan (2003) http://www.sadc.int/documentspublications/show/Regional Indicative Strategic Development Plan.pdf.
} 
other economic and non-economic development goals. ${ }^{, 47}$ Or particular relevance to this paper is the trade facilitation and integration agenda which also encompasses a development agenda.

SADC has six landlocked countries. ${ }^{48}$ However, they do have access to ports in neighbouring countries: Zambia to Dar-es-Salaam, Botswana to Walvis Bay, Malawi to Nacala, Zimbabwe to Beira, and Lesotho and Swaziland to Durban. While these are the closest ports to these territories, Durban is the "container hub port for Southern Africa" ${ }^{49}$ The dominance of South Africa's busiest port in the region means less traffic goes to other ports in the region. The extensive road network in Southern Africa allows for goods to move relatively easily from one country to another. While the quality of roads varies in the region, the major transport corridors are paved: the North-South Corridor from Durban to Dar-es-Salaam, the Trans-Kalahari Corridor from Walvis Bay to; Maputo Corridor; and the Dar-es-Salaam Corridors. ${ }^{50}$ Nevertheless, border delays and cumbersome customs procedures lead to slow movement of goods across borders. As a result, SADC has "the highest cost for transporting goods in the world", with up to $40 \%$ of the price of goods traded in the region being made up of transport costs. ${ }^{51}$ This in turn shows that many of the nontariff barriers to trade in the region work together to hamper the flow of goods at a faster rate than could be occasioned otherwise.

47 SADC Regional Indicative Strategic Development Plan http://www.sadc.int/aboutsadc/overview/strategic-pl/regional-indicative-strategic-development-plan/. ${ }^{48}$ Zimbabwe, Zambia, Botswana, Malawi, Lesotho, Swaziland.

${ }^{49}$ Peter Draper and Sören Scholvin, "The Economic Gateway to Africa? Geography, Strategy and South Africa's Regional Economic Relations" SAllA Occasional Paper 121 (2012) 37.

${ }^{50}$ See for further details: SADC Regional Infrastucture Development Master Plan: Transport Sector Plan http://www.sadc.int/files/9313/5293/3536/Regional Infrastructure Development Master Plan Transp ort Sector Plan.pdf 40.

${ }^{51}$ Bank of Tanzania "Intra-SADC Trade in Goods and Services (Including Assessing the Condition for the Dynamism of Intra-regional Trade)" (2014).

https://www.sadcbankers.org/Lists/News\%20and\%20Publications/Attachments/194/SADC\%20PAPE R\%20-FINAL\%20FOR\%20WEBSITE\%20\%28intra\%20trade\%29.pdf 12. 
The SADC Protocol on Transport, Communications and Meteorology seeks to establish efficient forms of transport, communication and meteorology within the region. ${ }^{52}$ The driving force of the Protocol is increased regional cooperation in these sectors. Should these be improved, there is greater scope to implement the Protocol on Trade, particularly with respect to trade facilitation. The Chirundu One-stop Border post offers a useful study into how border procedures can be reduced; allowing for increased and faster movement of freight transport, informal traders and the general public between Zambia and Zimbabwe. ${ }^{53}$ In order to test the feasibility of reducing border procedures and improve trade gains through improved efficiency, a One Stop Border Post (OSBP) was established at Chirundu - between Zimbabwe and Zambia - in 2009. North bound traffic (both passenger and freight) is cleared on the Zambian side of the border, while South bound traffic is cleared in Zimbabwe. Since the inauguration of the border, the clearance period for trucks has been reduced from 2-3 days to only 2-3 hours; while passengers are able to clear the border within 15 minutes. ${ }^{54}$ The improved efficiencies at the OSBP ensure that there is quicker movement of goods and people across the borders, which translates to increased welfare gains for consumers downstream. Should more OSBPs be established within the region, increased intra-regional trade and greater economies of scale could result. Southern Africa's busiest border is at Beitbridge, across the Limpopo River between Zimbabwe and South Africa. ${ }^{55}$ It would be highly beneficial to create a one-stop border at this port and help reduce delays and the high level of traffic; however, for the same reason, it would also be a rather uphill task.

\footnotetext{
52 SADC SADC Protocol on Transport, Communications and Meteorology http://www.sadc.int/documents-publications/show/815.

${ }^{53}$ Read generally Barney Curtis, "The Chirundu Border Post: Detailed Monitoring of Transit Times" (2012) http://siteresources.worldbank.org/EXTAFRSUBSAHTRA/Resources/DP10-Chirundu.pdf. ${ }_{54}$ Habiba Ben Barka "Border Posts, Checkpoints, and Intra-African Trade: Challenges and Solutions" (2012) 12.

55 Ibid at 7.
} 
SADC is deemed to have better infrastructure than other regions in Africa, however, there is need to improve what is already there before adequate gains can be made. ${ }^{56}$ "If Southern Africa's infrastructure could be improved to the level of the strongestperforming country in Africa (Mauritius), regional per capita growth performance would be boosted by some 3 percentage points. ${ }^{57}$ This means that trade volumes within SADC would grow, while facilitating increased exports to other regions worldwide ${ }^{58}$ However, such expansion and upgrading of infrastructure at a regionwide level would need a lot of capital investment and perhaps even more time - "\$2.1 billion a year over the course of a decade.. ${ }^{59}$ Even more funding would be required to maintain the infrastructure once it is completed.

Even if the challenge of infrastructure development is addressed, training has to be conducted to bring policies and procedures in line with what physical structures are in place to facilitate trade. Constructing more one-stop border posts will not automatically translate to shorter waiting times for truckers or passengers personnel at these posts need to see and experience policies coming alive not just at the regional level, but also at the national level, where much of the implementation will occur.

\footnotetext{
${ }^{56}$ Rupa Ranganathan andVivien Foster "The SADC's Infrastructure: A Regional Perspective" World Bank Policy Research Working Paper 5898 (2011) vii.

${ }^{57}$ Ibid at 2.

${ }^{58}$ Memory Dube "Analysing the Development Process" PERISA Case Study 3: Infrastructure 6. for Infrastructure Projects in SADC.

${ }^{59}$ lbid at 59.
} 


\section{Phase II ${ }^{60}$}

Phase II of the Case Studies project looked at ways in which some more immediate problems could be addressed. While a lot has been written in the academic context, GIZ sought to engage in targeted interventions in order to unblock some of the barriers that traders experienced across borders. ${ }^{61}$ This was important since any changes at the policy level would only be realised after a few years at the very least. Short term interventions with a shorter turnaround time can help ease certain processes along the trading chain and hopefully catapult macro-level changes in the long term.

Just as in Phase I, SAllA and GIZ engaged the participating regional business organisations to pick out a few barriers to focus on in the crafting of targeted intervention measures. Engaging with these regional bodies ensured that the proposed solutions were in line with what industry itself required. Furthermore, crafting these solutions meant that the results of the survey went further than other studies by actively engaging with survey participants post-survey in order to firmly address their concerns. The work has only just begun; hence it will be interesting to see how far the process of engagement goes beyond 2014.

An example of the approach used in the second phase of the study can be seen in the manner in which the SADC Bankers Association was approached in order to find

\footnotetext{
${ }^{60}$ See Lesley Wentworth "Regional Business Barriers: Unlocking Economic Potential in Southern Africa" available at http://www.thetradebeat.com/regional-institutions/regional-business-barriersunlocking-economic-potential-in-southern-africa.
} 
out how to level the playing field for small to medium scale farmers in Malawi who had problems with access to finance. ${ }^{62}$ This initiative led to the hosting of a dialogue in Malawi, bringing together multilateral development institutions, ${ }^{63}$ commercial bankers, microfinance institutions and the agricultural producers - essentially all relevant stakeholders. The idea behind this dialogue was to bring together all relevant stakeholders in order for them to talk about the problems the farmers were experiencing in obtaining capital for their projects and try to find solutions that work for all parties involved.

\section{SADC's Engagement of the Private Sector}

The RISDP's implementation plan envisaged engaging the private sector in regional integration initiatives. ${ }^{64}$ ASCII White Paper on Economic Policy Issues as a blueprint for engaging the private sector. ${ }^{65}$ However, the modalities of this implementation were never realised. Unfortunately, SADC only operated a private sector desk between 2003 and $2005 .^{66}$ This means that a lot of opportunities to engage with the private sector have not been harnessed. Perhaps this is what contributes to the lethargy to engage with SADC by some private sector players as they would feel that the regional body is not championing their cause effectively.

\footnotetext{
${ }^{62}$ See Case Study 1: Access to and Cost of Finance in Agriculture in Lesley Wentworth "Regional Business Barriers: Unlocking Economic Potential in Southern Africa" available at http://www.saiia.org.za/news/regional-business-barriers-unlocking-economic-potential-in-southernafrica .

${ }^{63}$ The World Bank and the United Kingdom's Department for International Development (DFID).

${ }^{64}$ See SADC RISDP (2003) "Chapter 3.6.4 - SADC Private Sector".

${ }_{65}^{6}$ ASCII White Paper on Economic Policy Issues/ (2001) http://www.ascci.info/index.php/publications.

${ }^{66}$ DFID Advancing Regional Integration in Southern Africa (2014) 91.
} 
Ms Wentworth noted that while many commentators have maintained that a stronger private sector will bring about a more robust regional integration agenda, the key to achieving this would be to organise it better. ${ }^{67}$ The moves to create a regional apex body for all business organisations in the region are responsive to this need. An institutionally sound apex body would give the private sector more leverage in terms of engaging with SADC as well as other policy and regulatory bodies in Southern Africa.

SADC wanted the apex body to be set up within its Secretariat. However, given the institutional weakness of SADC as well as the potential for the new body to be mired in bureaucracy, this was not deemed to be a viable solution. A potential solution is to house the apex body within the NEPAD Business Foundation. A meeting is to be held in Gaborone, Botswana, to flesh out this idea and hopefully launch the new regional apex business body to champion the cause of the private sector. ${ }^{68}$

In an effort to facilitate dialogue between the private sector and the Secretariats of COMESA, the EEC and SADC, TradeMark Southern Africa (TMSA) established the Mechanism for Reporting, Monitoring \& Eliminating Non-Tariff Barriers. ${ }^{69}$ Through this mechanism, private sector operators could report any non-tariff barriers they faced in their operations within the region. The barriers would then be passed onto the relevant SADC country for resolution. Companies have been very efficient at reporting non-tariff barriers, but their resolution has been lagging behind. ${ }^{70}$ The

\footnotetext{
67 Interview with Lesley Wentworth.

68 Ibid.

69 TrademarkSA 'The Mechanism for Reporting, Monitoring \& Eliminating Non-Tariff Barriers' http://www.tradebarriers.org/.

${ }_{70}$ Lesley Wentworth 'Introduction: The Current Status of the Business-Enabling Environment' http://www.saiia.org.za/doc download/614-sadc-business-barriers-the-current-status-of-the-businessenabling-environment?Itemid=428 10.
} 
future of the mechanism was unsure since the DFID-funded TMSA project has come to an end. ${ }^{71}$ However, COMESA has since taken over its management. ${ }^{72}$

\section{Conclusion}

The goal of the case studies was not only to create possibilities to influence regional policy, but also to facilitate the crafting of practical solutions to some of the barriers faced by companies conducting business in SADC and to engage in a form of advocacy on behalf of traders in the region. It will be interesting to see how further dialogues between various stakeholders are organised in order to address some of the concerns raised by business people in the region.

One of the most important outcomes of the $9^{\text {th }}$ WTO Ministerial Meeting in Bali in 2013 was the negotiation of the WTO Trade Facilitation Agreement (TFA). ${ }^{73}$ Hong Kong, China was the first country to ratify the TFA; however, it will only come into effect after two thirds of WTO Members ratify it. ${ }^{74}$ WTO Director-General, Roberto Azevêdo, has averred that the implementation of the TFA will benefit Africa through increased regional integration. ${ }^{75}$ Trade facilitation will increase Africa's competitiveness. Indeed, it will boost the gains to be made from investments in

\footnotetext{
${ }^{71}$ TradeMarkSA 'Closure of TradeMark Southern Africa' http://www.trademarksa.net/about us/programme news/closure-trademark-southern-africa. ${ }_{72}$ COMESA Report of the Thirty Second Meeting of the Council of Ministers, Kinshasa, Democratic Republic of Congo 22 - 24 February 2014 http://www.comesa.int/attachments/article/1111/140406 32nd\%20Council\%20Report.pdf 19. ${ }_{74}^{73}$ WTO Agreement on Trade Facilitation WT/L/931.

74 WTO 'Hong Kong, China first to ratify WTO's Trade Facilitation Agreement' http://www.wto.org/english/news e/news14 e/fac 10dec14 e.htm.

${ }^{75}$ Roberto Azevedo 'Azevêdo: Africa set to benefit from WTO breakthrough on Bali' Speech at the African Union Conference of Ministers of Trade on 4 December in Addis Ababa, Ethiopia http://www.wto.org/english/news e/spra e/spra43 e.htm.
} 
infrastructure, particularly in the transport sector. ${ }^{76}$ However, there is still need for greater political commitment and follow through in terms of operationalising the mandate of the Agreement.

Companies need to go into Southern Africa with an opportunity-focused approach which factors in relevant risks instead of assuming that the landscape will be difficult to operate in even without any experience of this. On this point, EY research indicates that "on some key indicators, the much-vaunted BRIC countries are more risky or more difficult than many important African markets." ${ }^{177}$

Only through increased integration can SADC achieve the gains that would turn it into a real economic powerhouse. The regional body also needs to engage better with the private sector in order to address concerns specific to them. SADC has discussed and adopted various policy documents aimed at facilitating trade, ${ }^{78}$ but implementation still lags behind.

\footnotetext{
${ }^{76}$ Patrick Kanyimbo and Calvin Manduna, 'Trade facilitation in the Bali Package: What's in it for Africa?', December 16, 2013 http://www.afdb.org/en/blogs/integrating-africa/post/trade-facilitation-inthe-bali-package-whats-in-it-for-africa-12698/

${ }_{77}$ EY Attractiveness Survey 'EY Attractiveness Survey' at 90

78 These include: The Traders' Guide on SADC Rules of Origin; Free Trade Area Leaflet; SubCommittee on Customs Cooperation Indicative Strategic Plan; SADC Coordinated Border Management Guidelines; Private Sector Involvement Strategy in Customs Matters; SADC Customs Information Communication Technology Strategy; Audit of the Regional Customs Instruments and International Conventions among others.
} 